\title{
Electrochemical Label-Free Immunosensor for The Detection of Epithelial Sodium Channels Using Gold Modified Screen-Printed Carbon Electrode
}

\author{
Yeni Wahyuni Hartati ${ }^{1}$, Nadya Putri Satriana ${ }^{2}$, Shabarni Gaffar ${ }^{3}$, Jacob Yan Mulyana ${ }^{4}$, Santhy \\ Wyantuti $^{5}$, Yulia Sofiatin ${ }^{6}$ \\ \{yeni.w.hartati@unpad.ac.id¹, nadya.satput@gmail.com², shabarni.gaffar@unpad.ac.id ${ }^{3}$, \\ y.mulyana@tmu.ac.jp ${ }^{4}$, santhy.wyantuti@unpad.ac.id ${ }^{5}$, yulia.sofiatin@unpad.ac.id $\left.{ }^{6}\right\}$ \\ Department of Chemistry, Faculty of Mathematics and Natural Sciences, Universitas Padjadjaran \\ Bandung, Indonesia ${ }^{1}$. \\ Department of Applied Chemistry and Graduated School of Urban Environmental, Tokyo Metropolitan \\ University, Japan². \\ Department of Public Health, Faculty of Medicine, Universitas Padjadjaran Bandung, Indonesia ${ }^{3}$.
}

\begin{abstract}
The epithelial sodium channel $(\mathrm{ENaC})$ is a protein used in maintaining sodium levels and related to hypertension. ENaC protein is abundant in lung, gut, and kidney. An electrochemical immunosensor has developed to detect the level of $\mathrm{ENaC}$ in the urine. The electrode used was screen printed carbon electrode-gold (SPCE-Au) via $\mathrm{HAuCl} 4$ electrodeposition. Anti-ENaC was immobilized onto the SPCE-Au with 3mercaptopropinonic (MPA) linker between gold and anti-ENaC. Various concentration of standard $\mathrm{ENaC}$ was used to determine the optimum experiment condition and analytical parameters. The interaction of Anti-ENaC that immobilized on the electrode surface with $\mathrm{ENaC}$ was measured as a ferric cyanide response by differential pulse voltammetry. The SPCE-Au has increased the ferric cyanide peak current by about $482 \%$ compare to SPCE bare. Immobilization of the Anti-ENaC decreases the peak current of about $53 \%$. The optimum conditions of the experiment were obtained; $0.01 \mathrm{M}$ of MPA for $20 \mathrm{~min}$ incubation time, and $0.5 \mu \mathrm{g} / \mathrm{mL}$ of anti-EnaC concentration. The sensitivity of the immunosensor was 10.571 , the limit of detection of $0.037 \mathrm{ng} / \mathrm{mL}$, and the limit of quantification $0.123 \mathrm{ng} / \mathrm{mL}$ for $\mathrm{ENaC}$ concentration range from 0.1 to 1.5 $\mathrm{ng} / \mathrm{mL}$. Furthermore, the proposed immunosensor can be used to measure the concentration of $\mathrm{ENaC}$ as a biomarker of hypertension in clinical urine samples.
\end{abstract}

Keywords: Anti-ENaC, Electrochemical immunosensor, Epithelial sodium channels $(\mathrm{ENaC})$, screen printed carbon electrode (SPCE).

\section{Introduction}

Epithelial Sodium Channel or $\mathrm{ENaC}$ is a protein that concists of four subunits $\alpha, \beta, \gamma$, and $\delta$, which bound to the permeable membrane. $\mathrm{ENaC}$ has a functions as an ion channel that is selective to the $\mathrm{Na}^{+}$ion [1]. ENaC protein is abundant in the lungs, intestines, and kidneys. In the kidney, an $\mathrm{ENaC}$ protein associated with sodium intake in the body related to hypertension [2],[3]. The ENaC protein is responsible for regulating sodium balance, blood volume, and blood pressure [4]. Excessive sodium reabsorption by the kidneys is known to increase the risk of hypertension. Hypertension occurs because of the increase of fluid in the circulation caused 
by abnormalities of kidney function so that it is unable to remove a certain amount of salt and water from the body. Thus the volume of blood in the body also increases, therefore the blood pressure will also increases [5]. Urine is the closest source of the kidney, so it can be used as a sample to detect $\mathrm{ENaC}$ concentration. The method to determined $\mathrm{ENaC}$ was generally carried out by the ELISA. ELISA has been used to detect and measure ENAC level in the urine samples of patients with hypertensive history, without history of hypertension, and nonhypertension. The conclusions showed that from 100 samples which were tested, ENaC concentrations in patients with hypertension were equal to or more than $4.0 \mathrm{ng} / \mathrm{mL}$, in patients without a history of hypertension were $2.7 \mathrm{ng} / \mathrm{mL}$ and in patients non-hypertension were equal to or less than $1.12 \mathrm{ng} / \mathrm{mL}$. The concentration of $\mathrm{ENaC}$ protein detected in urine varies depending on hypertension status, history of hypertension, and sex [3].

In addition to ELISA, other method for the detection of biomarker proteins have been developed, such as electrochemical immunosensors. The advantages of the immunosensor method include a more straightforward, faster, and more comfortable operation, therefore it can be developed to be portable for point of care. Baradoke [6] developed an electrochemical immunosensor to detect anti-CA125 using a screen printed with gold and platinum nanostructured carbon electrode modified and obtained a detection limit value of $0.419 \mathrm{ng} / \mathrm{mL}$. An immunosensor to detect HER2 biomarkers using a gold-modified screen-printed carbon electrode also has developed with a detection limit value of $2.9 \mathrm{ng} / \mathrm{mL}$ [7]. The use of SPCE modified with gold was reported increase sensitivity and selectivity [8].

In this study, an electrochemical immunosensor method was applied to detect $\mathrm{ENaC}$ proteins using gold-modified SPCE, then immobilization of antibodies on the surface of the modified electrode was done through the covalent bond method. We determined the optimum experimental conditions and experimental influencing parameters for the standard $\mathrm{ENaC}$ protein solution and in the urine sample.

\section{Materials and Methods}

\subsection{Materials}

$\mathrm{ENaC}$ protein (Abcam, UK), anti-ENaC antibodies (Abcam, UK), hydrochloric acid ( $\mathrm{HCl})$, chloroauric acid (HAuCl4), 3-mercaptopropinoic acid (MPA), ethanol, ethanolamine, potassium ferric cyanide $\left(\mathrm{K}_{3}\left[\mathrm{Fe}(\mathrm{CN})_{6}\right]\right)$, potassium hydrogen phosphate $\left(\mathrm{KH}_{2} \mathrm{PO}_{4}\right)$, potassium chloride $(\mathrm{KCl})$, sodium hydroxide $(\mathrm{NaOH})$, sodium chloride $(\mathrm{NaCl})$, sodium hydrogen phosphate $\left(\mathrm{Na}_{2} \mathrm{HPO}_{4}\right)$, N-ethyl-N '- [3-dimethylaminopropyl] carbodiimide (EDC), and Nhydroxy succinimide (NHS), all from Merck (Germany), and redistilled water (PT Ikapharmindo Putramas, Indonesia).

\subsection{Apparatus}

Voltammetric and electrochemical impedance spectrometry measurements using the Zimmer and Peacock potentiostat connected to the computer using PS Trace 5.4 software (UK). Screen printed carbon electrode (SPCE) (GSI Technologies, USA) were used as electrodes. JSM-7500F scanning electron microscope (SEM) (Jeol, US), an autoclave sterilization (Prestige Medical Series 2100), weighing balance (Mettler Toledo AL204), 
BUCHI B-490 rotative evaporator (Switzerland), centrifuge (Corning, New York), and micropipette (Eppendorf, Germany).

\subsection{Modification of SPCE with Gold and Its Characterization}

The scheme of the entire stages of the immunosensor method is shown in Figure. 1. The first step is to modify the screen printed carbon electrode with $\mathrm{HAuCl}_{4}$ electrodeposition. The SPCE used consists of carbon as a working electrode, a carbon auxiliary electrode, and a reference electrode, $\mathrm{Ag} / \mathrm{AgCl}$. SPCE was dropped with an $80 \mu \mathrm{L}$ of $1.0218 \mathrm{mg} / \mathrm{mL} \mathrm{HAuCl}_{4}$ solution and was electrodeposited by using differential pulse voltammetry with a potential range from -0.5 to $+0.5 \mathrm{~V}$ at a scanning rate of $0.008 \mathrm{~V} / \mathrm{s}$ [9]. Then rinse carefully with redistilled water and then dry it in air. The modified SPCE-Au was electrochemically characterized by differential pulse voltammetry using a redox system $10 \mathrm{mM} \mathrm{K}_{3}\left[\mathrm{Fe}(\mathrm{CN})_{6}\right]$ solution in $0.1 \mathrm{M} \mathrm{KCl}$ with the potential range from -0.5 to $+0.5 \mathrm{~V}$, at a scanning rate 0.008 $\mathrm{V} / \mathrm{s}$. Furthermore, the electrochemical impedance spectroscopic response is also determined. SPCE before and after modification were characterized by SEM.

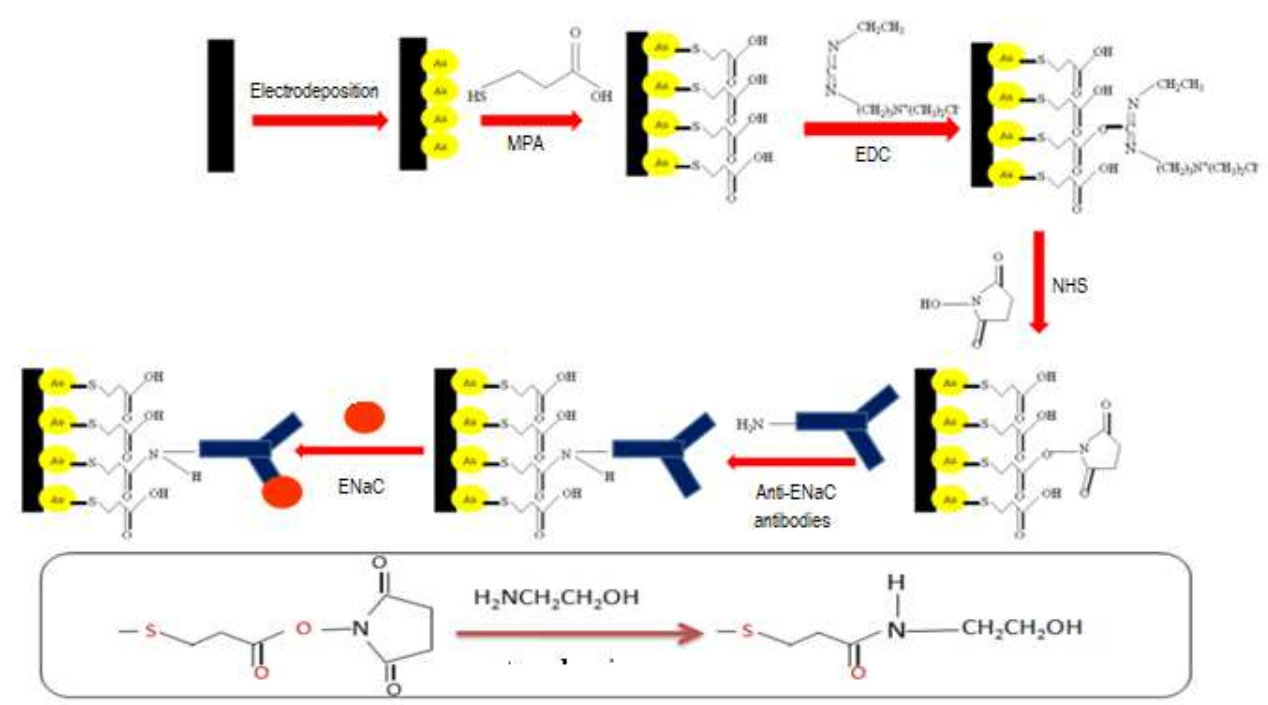

Figure 1.Schematic of immunosensor for the detection of ENaC [10].

\subsection{Anti-ENaC (Ab) Immobilization on the SPCE-Gold Surface}

SPCE-Au was dropped with $40 \mu \mathrm{L}$ of $0.01 \mathrm{M}$ MPA solution in ethanol for $20 \mathrm{~min}$ at 25 ${ }^{\circ} \mathrm{C}$ to form SPCE-Au/MPA, then rinse with ethanol. Afterwards, $30 \mu \mathrm{L}$ of EDC/NHS solution each $0.1 \mathrm{M}$ were dropped on SPCE-Au surface and incubated for one hour at temperature $25^{\circ} \mathrm{C}$, then rinsed with redistilled water. Furthermore, the electrode was dropped with $30 \mu \mathrm{L}$ of $0.5 \mu \mathrm{g} / \mathrm{mL}$ anti-ENaC antibodies and incubated for one hour at $25^{\circ} \mathrm{C}$ to obtain the SPCE$\mathrm{Au} / \mathrm{MPA} / \mathrm{Ab}[7,8,10]$. 


\subsection{The detection of ENaC by immunosensor}

The non-specific binding site of the electrode surface was blocked using $30 \mu \mathrm{L}$ of ethanolamine solution and incubated for 20 minutes at $25^{\circ} \mathrm{C}$, after the anti-ENaC antibody was successfully immobilized on the electrode surface. The electrode was then rinsed with PBS pH 7.4. Then the electrode was incubated in a $30 \mu \mathrm{L}$ of ENaC antigen (an absolute concentration) and incubated for 30 minutes at $25{ }^{\circ} \mathrm{C}$. Each concentration was measured by differential pulse voltammetry using a redox system $10 \mathrm{mM} \mathrm{K}_{3}\left[\mathrm{Fe}(\mathrm{CN})_{6}\right]$ solution in $0.1 \mathrm{M}$ $\mathrm{KCl}$ with the potential range from -0.5 to $+0.5 \mathrm{~V}$ at a scanning rate of $0.008 \mathrm{~V} / \mathrm{s}$ to obtain SPCE-Au/MPA/Ab/Ag $[7,8,10]$.

\subsection{Electrochemical measurements}

Electrochemical measurements have been carried out to determine whether MPA, anti$\mathrm{ENaC}$ antibodies, and $\mathrm{ENaC}$ have been immobilized on SPCE before and after modification. The measurements were done by differential pulse voltammetry with the potential range -0.5 to $+0.5 \mathrm{~V}$, at a scanning rate of $0.008 \mathrm{~V} / \mathrm{s}$. $30 \mu \mathrm{L}$ of $10 \mathrm{mM} \mathrm{K}_{3}\left[\mathrm{Fe}(\mathrm{CN})_{6}\right]$ solution in $0.1 \mathrm{M}$ $\mathrm{KCl}$ was dropped onto the surface of the electrodes as a redox marker, then measured by cyclic voltammetry and electrochemical impedance spectroscopy.

\section{Results and Disscussion}

\subsection{Gold-modified SPCE characterization}

The morphological surfaces of SPCE characterized by the scanning electron microscope (SEM) showed differences in the SPCE surface before and after modification with gold. Figure. 2A shows the SPCE bared, and Figure. 2B shows the SPCE morphology after modification. It can be seen that at the surface of SPCE after modification, the gold is well distributed and evenly distributed throughout the electrode surface. The modified SPCE was also characterized by differential pulses voltammetry. Figure.ure $2 \mathrm{C}$ shows the differential pulse voltammogram of $10 \mathrm{mM} \mathrm{K}_{3}\left[\mathrm{Fe}(\mathrm{CN})_{6}\right]$ as redox system in a $0.1 \mathrm{M} \mathrm{KCl}$ on SPCE and SPCE-Au. A higher peak current in SPCE-Au indicated that modification of electrode with gold was effective to increase the conductivity of the electrode, thereby increasing the electron transfer between electrodes and analytes [11]. Figure.ure 2D depicts the EIS pattern, which shows reduced impedance/resistance after modification SPCE with gold. The ferric cyanide current response generated at voltammetry is the opposite of the EIS curve decreasing impedance. 

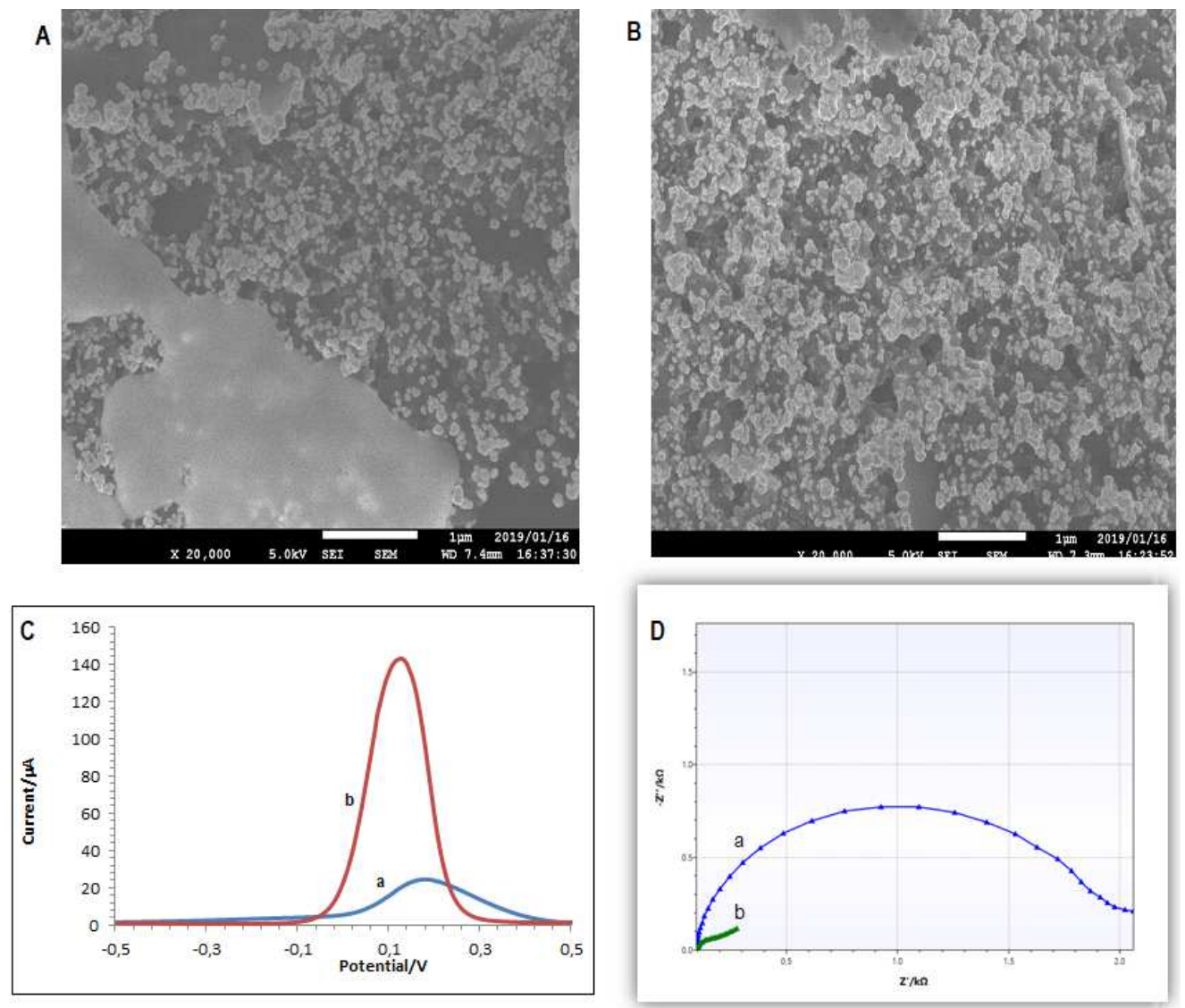

Figure. 2. Surface morphology of SPCE before modification with gold (A); SPCE-Au after electrodeposition of $\mathrm{HAuCl}_{4}$ (B); Differential pulse voltammograms of $10 \mathrm{mM}$ of $\mathrm{K}_{3}\left[\mathrm{Fe}(\mathrm{CN})_{6}\right]$ in $0.1 \mathrm{M} \mathrm{KCl}$ solution on SPCE bare of $\mathrm{a}$, and $\mathrm{b}$ on SPCE-Au surfaces $(\mathrm{C})$; The scanning rate of the differential pulse voltammetry is $0.008 \mathrm{~V} / \mathrm{s}$ in the potential range of $-0.5 \mathrm{~V}$ to $+0.5 \mathrm{~V}$. The Nyquist plots of $10 \mathrm{mM}$ of $\mathrm{K}_{3}\left[\mathrm{Fe}(\mathrm{CN})_{6}\right]$ in $0.1 \mathrm{M} \mathrm{KCl}$ solution on the SPCE bare of a, and on the SPCE-Au surface, $\mathrm{b}$. The decreasing of the curves was obtained using electrochemical impedance spectrophotometry at a frequency range of 0.05 to $50 \mathrm{kHz}$, at $0.25 \mathrm{~V}$ (D).

\subsection{Immobilization of Anti-ENaC Antibodies on the Electrode Surface}

Immobilization of anti-ENaC onto the SPCE-Au surface was done based on the covalent bonding. The covalent bond of antibodies directly transducer surface that functionalizes the gold surface via organic alkanethiol, disulfide, or sulfide. The strong affinity of sulfur atoms to the surface of gold due to the interaction of the sulfur-gold atom is $45 \mathrm{kcal} / \mathrm{mol}$, so it can form stable covalent bonds [12]. The alkanethiol group used is MPA (3-mercaptopropionic acid) is an organosulfur compound that can bind to gold through Au-S bonds [12]. The other terminal end of MPA is a carboxylic group, so that the carboxyl group can bind chemically to another group. To eliminate thiols that physically adsorbed, then the electrode must rinsed with ethanol. 
The carboxyl group that has modified the gold surface is then activated with N-ethyl-N'[3-dimethylaminopropyl] carbodiimide/N-hydroxysuksinamide solution to form a reactive succinamide ester, as shown in Figure. 1. This reactive group becomes ready to bind to the primary amine group from anti-ENaC antibodies covalently on the SPCE-Au surface. After the addition of anti-ENaC antibodies, SPCE-Au/MPA/EDC is formed: NHS/Ab. The addition of ethanolamine was needed to avoid non-specific binding on the surface of the electrode that has been immobilized by anti-ENaC antibodies. The $-\mathrm{COOH}$ group on the surface of the electrode that does not bind to the antibodies will be covered with ethanolamine so that antibodies immobilized on the surface of the immunosensor have a good orientation. Despite that, ethanolamine is used to block the electrode surface to avoid unspecified binding site [10]. Rinsing process with PBS buffer $\mathrm{pH} 7.4$ is needed to clear non-binding species. The immunosensor is now ready for binding the $\mathrm{ENaC}$ antigen in the sample.

Figure. 3 shows the difference of peak current on the differential pulse voltammograms of ferric cyanide redox activity on SPCE bare, after modification and after addition of immunoreagent. A highest increase of peak current occur when the SPCE is modified with gold (curves a and b), then decreases gradually after addition of MPA (c), the addition of MPA/EDC-NHS (d), and addition of MPA/EDC-NHS/anti-ENaC (e). The electron transfer of $\left[\mathrm{Fe}(\mathrm{CN})_{6}\right]^{3-/ 4-}$ species at the electrode was blocked gradually after addition of immunoreagents and marked by a decrease in peak current.

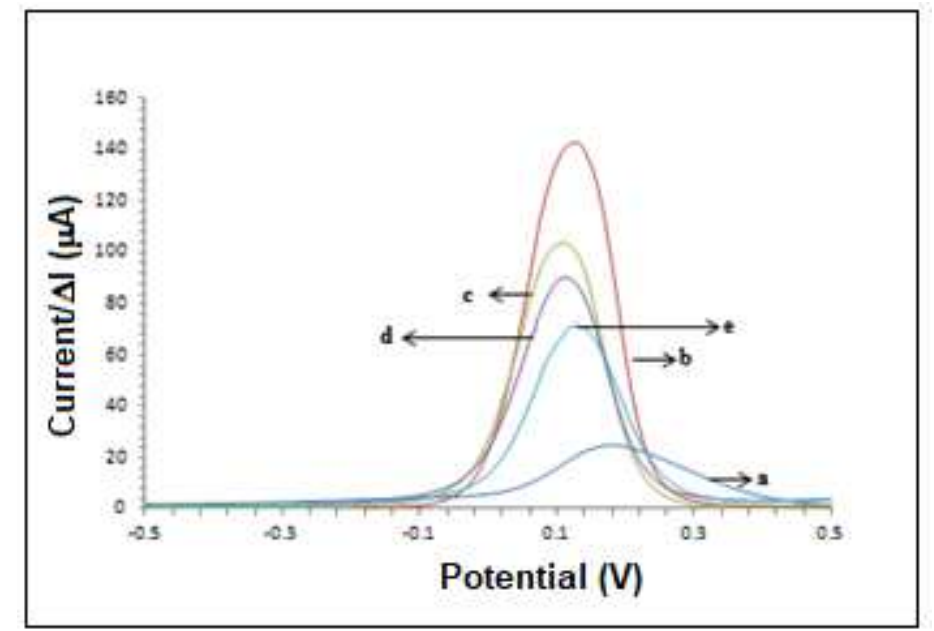

Figure 3.Differential pulsevoltammogramsof SPCE bare (a), SPCE-Au (b), SPCE-Au/MPA (c), SPCE$\mathrm{Au} / \mathrm{MPA} / \mathrm{EDC}-\mathrm{NHS}$ (d), and SPCE-Au/MPA/EDC-NHS/Anti-EnaC (e), which is dropped with a 10 mM0f $\mathrm{K}_{3}\left[\mathrm{Fe}(\mathrm{CN})_{6}\right]$ in $0.1 \mathrm{M} \mathrm{KCl}$ solution. The scanning rate is $0.008 \mathrm{~V} / \mathrm{s}$ in the potential range of $-0.5 \mathrm{~V}$ to $+0.5 \mathrm{~V}$.

To observe whether antibodies and antigens had immobilized on the electrode surface also characterized using a scanning electron microscope (SEM). Figure. 4 depics the surface morphology of SPCE-Au after being covered by anti-ENaC (SPCE-Au/MPA/EDC-NHS/Ab) (a), and SPCE-Au/MPA/EDC-NHS/Ab/Ag after being covered by ENaC protein antigen (SPCE-Au/MPA/EDC-NHS/Ab/Ag) (b). The Figure.ure shows that the SPCE-Au/MPA/EDC- 
$\mathrm{NHS} / \mathrm{Ab}$ surface that is coarse and porous. Despite SPCE-Au/MPA/EDC-NHS/Ab/Ag shows a porous but has a more uniform surface.
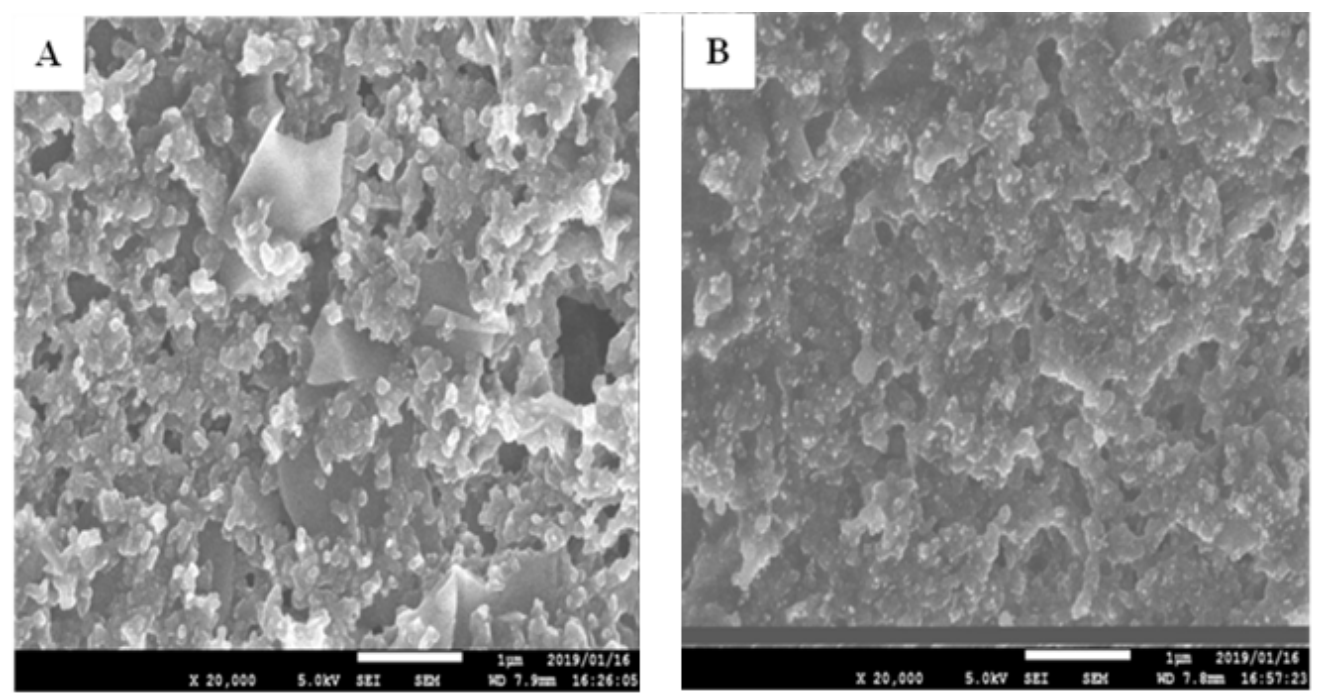

Figure 4. Results of magnification of 20,000x SEM from the surface a) SPCE-Au/MPA/EDC-NHS/Ab; b) SPCE-AU/MPA/EDC:NHS/Ab/Ag

\subsection{Optimum Experiment Conditions}

The effect of the concentration of MPA (3-mercaptopropionic acid) on the efficiency of anti-ENaC antibody immobilization was tested using differential pulse voltammetry with a potential range of $-0.5 \mathrm{~V}$ to $+0.5 \mathrm{~V} / \mathrm{s}$ of the $10 \mathrm{mM} \mathrm{K} 3\left[\mathrm{Fe}(\mathrm{CN})_{6}\right]$ containing $0.1 \mathrm{M} \mathrm{KCl}$ solution. The optimization of MPA concentration needs to be determined because the optimum number of carboxylic groups covering the electrode surface determines the amount of antibodies bound. However, too high a level of MPA can cause damage to a thin layer of screen printed materials, and make of unstable measurements. In this study, $0.01 \mathrm{M}$ of MPA was chosen as optimum concentration, because levels higher than $0.01 \mathrm{M}$ damaged the SPCE surface.

The duration of incubation of MPA (3-mercaptopropionic acid) on the SPCE-Au surface also affected the efficiency of anti-ENaC antibody immobilization. It can be seen in the voltammogram of the differential pulses of the $10 \mathrm{mM} \mathrm{K}_{3}\left[\mathrm{Fe}(\mathrm{CN})_{6}\right]$ containing $0.1 \mathrm{M} \mathrm{KCl}$ solution in the potential range of $-0.5 \mathrm{~V}$ to $+0.5 \mathrm{~V} / \mathrm{s}$. Figure. 5 shows that the longer the MPA incubation time in SPCE-Au, the lowered the peak current, this explains the more MPA that is emitted by gold on the electrode surface. At the incubation time of 5 and 10 minutes, the flow is almost the same and decreases at the incubation time of 20 minutes. When the incubation time was increased to 30 minutes, the peak current height was nearly 20 minutes incubation time, so 20 minutes was chosen as the optimum incubation time for MPA. 


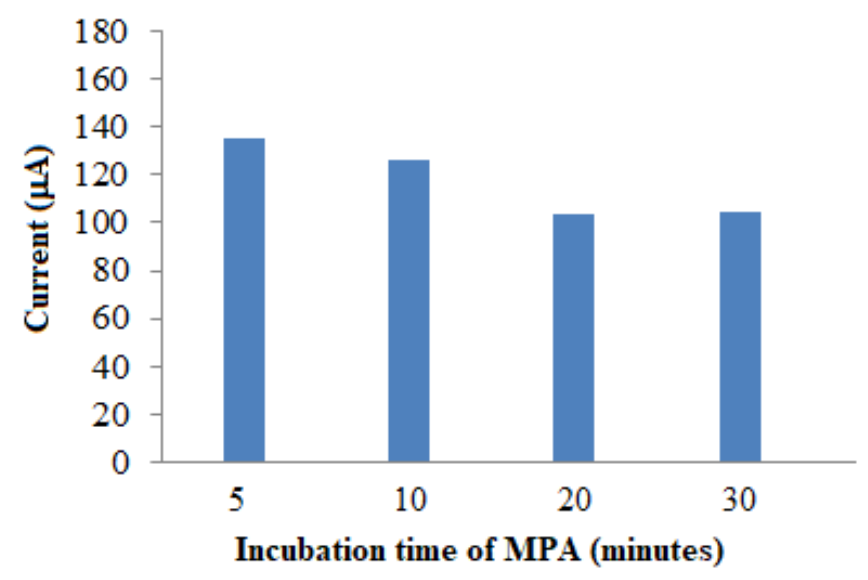

Figure 5. Effect of MPA incubation time on the peak current of the $10 \mathrm{mM} \mathrm{K}_{3}\left[\mathrm{Fe}(\mathrm{CN})_{6}\right]$ containing $0.1 \mathrm{M} \mathrm{KCl}$ solution with differential pulse voltammetry. The scanning rate is $0.008 \mathrm{~V} / \mathrm{s}$ in the potential range of $-0.5 \mathrm{~V}$ to $+0.5 \mathrm{~V}$. MPA incubation time: $5,10,20$, and $30 \mathrm{~min}$

The high concentration of anti-ENaC antibodies attached to the SPCE-Au/MPA surface will affect the number of $\mathrm{ENaC}$ antigens as analytes, which are bound to $\mathrm{Ab}-\mathrm{Ag}$. The efficiency of this anti-ENaC immobilization was tested by differential pulse voltammetry with a potential range of $-0.5 \mathrm{~V}$ to $+0.5 \mathrm{~V} / \mathrm{s}$ in the $10 \mathrm{mM} \mathrm{K}_{3}\left[\mathrm{Fe}(\mathrm{CN})_{6}\right]$ containing $0.1 \mathrm{M} \mathrm{KCl}$ solution. The concentration of anti-ENaC is essential in the development of immunosensors because it is associated with the sensitivity of the detection of immunosensors to $\mathrm{ENaC}$ antigens. The variation of the Anti-ENaC concentrations tested were $0 ; 0.05 ; 0,1 ; 0.25 ; 0.5$; $1.0 ; 1.5 ;$ and $2.0 \mu \mathrm{g} / \mathrm{mL}$.

Figure. 6 shows the effect of the anti-ENaC concentration on the height of ferric cyanide peak currents. The decrease in current occurs in proportion to the increase in the anti-ENaC antibody concentration from $0.05 \mu \mathrm{g} / \mathrm{mL}$ to reaching $0.5 \mu \mathrm{g} / \mathrm{mL}$. It is because antibodies attach to the surface of the electrode via a connector (EDC-NHS) with the appropriate orientation. That causes the orientation of the antibody to be immobilized better and more so that it can participate in immunoreaction. The concentration of anti-ENaC antibodies that are too low will produce a lower current because too few antibodies are immobilized. Then the current increases in the concentration of antibodies $1 \mu \mathrm{g} / \mathrm{mL}$ to reach $2 \mu \mathrm{g} / \mathrm{mL}$ in Figure. 6 . That is because a higher number of antibodies can increase the chaos of the antibody attachment arrangement and produce steric obstruction of the immunoreaction. The antibodies immobilized on the surface of the electrode are already saturated so that they interfere with the immobilization process themselves and produce a poor orientation which reduces the number of anti-ENaC antibodies attached to the MPA [13]. According to Ronkainen et al. [14], the density or number of antibodies that are immobilized on the surface of the electrode should not be too high because it can cause steric obstruction between antibodies at the electrode which will reduce its recognition activity. Thus, the concentration of $0.5 \mu \mathrm{g} / \mathrm{mL}$ was chosen as the optimum antibody concentration. 


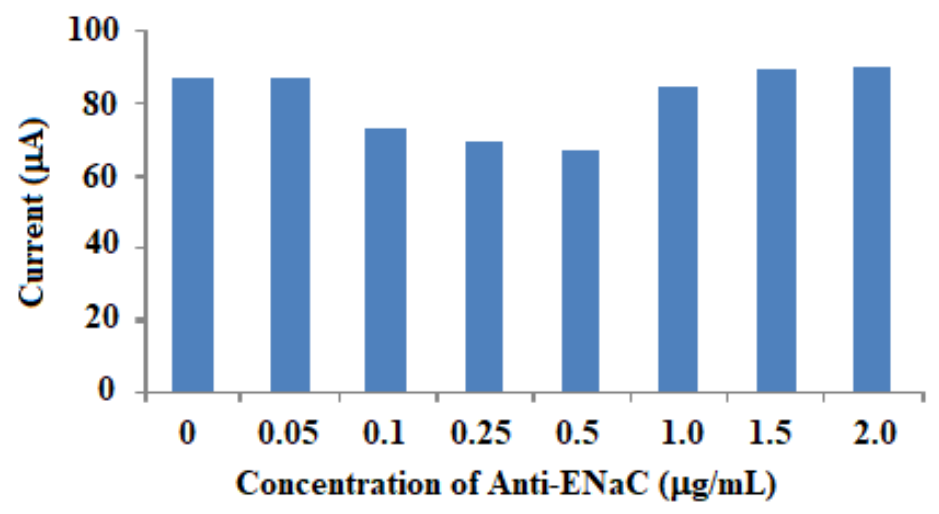

Figure 6. Effect of anti-ENaC antibody concentration on the peak of of the $10 \mathrm{mM} \mathrm{K}_{3}\left[\mathrm{Fe}(\mathrm{CN})_{6}\right]$ containing $0.1 \mathrm{M} \mathrm{KCl}$ solution with differential pulse voltammetry. The scanning rate is $0.008 \mathrm{~V} / \mathrm{s}$ in the potential range $-0.5 \mathrm{~V}$ to $+0.5 \mathrm{~V}$. The anti-ENaC antibody concentration: $0 ; 0.05 ; 0,1 ; 0.25 ; 0.5 ; 1$; $1.5 ; 2 \mu \mathrm{g} / \mathrm{mL}$.

\subsection{Performance of Immunosensor}

Various concentrations of $\mathrm{ENaC}$ antigens were applied to the immunosensor in the range of $0.1-5.0 \mathrm{ng} / \mathrm{mL}$. The measurement of the decrease in the redox system current of $\mathrm{K}_{3}\left[\mathrm{Fe}(\mathrm{CN})_{6}\right]$ solution using differential pulse voltammetry in the potential range -0.5 to +0.5 $\mathrm{V}$ and the scanning rate of $0.008 \mathrm{~V} / \mathrm{s}$ is inversely proportional to increase $\mathrm{ENaC}$ concentration. Triplicate measurements were carried out. The voltammograms of $0.1-1.5 \mathrm{ng} / \mathrm{mL}$ of the $\mathrm{ENaC}$ antigen is shown in Figure 7. For concentrations higher than $1.5-5 \mathrm{ng} / \mathrm{mL}$ it shows a linear relationship with a lower slope (data not shown). Furthermore, to calculate the limit of detection of measurement using a linear equation of $0.1-1.5 \mathrm{ng} / \mathrm{mL}$ ranges.

Figure $7 \mathrm{~A}$ shows the higher concentration of $\mathrm{ENaC}$ antigen in proportion to the lower peak current produced. The $\mathrm{ENaC}$ antigen is a large biomolecule that has not electroactive characteristics. The more $\mathrm{ENaC}$ antigens that are bound to antibodies immobilized on the electrode surface, the electron transfer to the electrode is increasingly blocked.

Figure 7B shows a plot of the calibration curve that states the relationship of variations in the concentration of $\mathrm{ENaC}$ antigens to the peak response of ferric cyanide currents. The linear relationship for the calibration curve obtained $\Delta \mathrm{I}=10.571[\mathrm{ENaC}]+5.8191$ with the value of $\mathrm{R}^{2}=0.9992$. The sensitivity of the method was obtained at 10,571 . The limit of detection (LOD) was calculated from the equation $Y=Y_{b}+3 S_{b}, Y b$ is the intercept of the calibration curve ( $a$ ), and $S_{b}$ is the $S_{X / Y}$ which estimates the random errors in the $Y$-direction [15]. The LOD was obtained of $0.037 \mathrm{ng} / \mathrm{mL}$, and a quantification limit of $0.123 \mathrm{ng} / \mathrm{mL}$. 


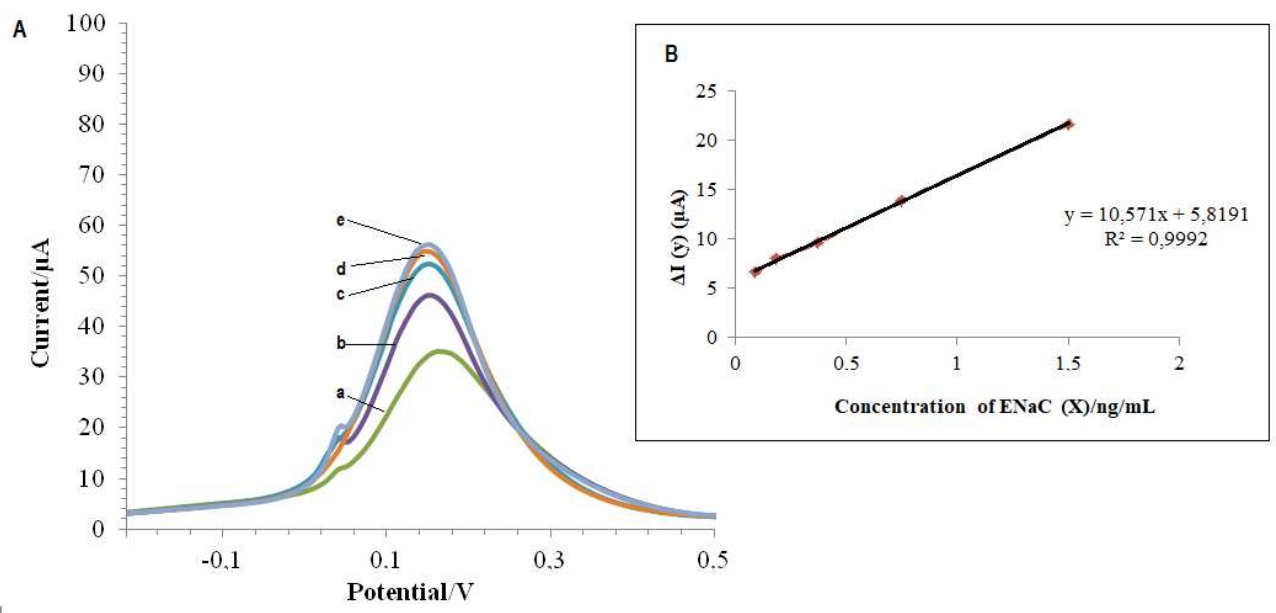

Figure 7. Differential pulse voltammogram of various $\mathrm{ENaC}$ antigen concentration $1.5 \mathrm{ng} / \mathrm{mL}$ (a), 0.75 $\mathrm{ng} / \mathrm{mL}$ (b), $0.375 \mathrm{ng} / \mathrm{mL}$ (c), $0.75 \mathrm{ng} / \mathrm{mL}$ (d), and $0.1 \mathrm{ng} / \mathrm{mL}$ (e). The response of $10 \mathrm{mM}$ $\mathrm{K}_{3}\left[\mathrm{Fe}(\mathrm{CN})_{6}\right]$ containing $0.1 \mathrm{M} \mathrm{KCl}$ solution with scanning $0.008 \mathrm{~V} / \mathrm{s}$ in the potential range -0.5 $\mathrm{V}$ to $+0.5 \mathrm{~V}$. B. The calibration curve was for various concentration of $0.1-1.5 \mathrm{ng} / \mathrm{mL}$.

Table1.Comparison of proteins as biomarker detection by immunosensor methods

\begin{tabular}{lllc}
\hline Methods & $\begin{array}{l}\text { Limit of detection } \\
(\mathrm{ng} / \mathrm{mL})\end{array}$ & $\begin{array}{l}\text { Linear range } \\
(\mathrm{ng} / \mathrm{mL})\end{array}$ & Reference \\
\hline $\begin{array}{l}\text { SPCE- gold and platinum nanostructures } \\
\text { for anti CA125 detection }\end{array}$ & 419 & $450-2,916$ & {$[6]$} \\
$\begin{array}{l}\text { SPCE-Gold for HER2 breast cancer } \\
\text { biomarker detection }\end{array}$ & 2.9 & $0.005-10.0$ & {$[7]$} \\
$\begin{array}{l}\text { Reduced graphene oxide chitosan- } \\
\text { aptamer for HER2 detection }\end{array}$ & 0.21 & $0-50.0$ & {$[16]$} \\
SPCE-Au for ENaC protein detection & 0.037 & $0.1-5.0$ & This work \\
\hline
\end{tabular}

The LOD that is obtained in this study is lower than the same previous principal immunosensor research for other proteins as biomarkers detection. It can be seen in Table 1 . With a low detection limit, it can be used to record the $\mathrm{ENaC}$ protein content found in clinical samples of hypertension and non-hypertension.

\section{Conclusion}

An electrochemical immunosensor for detection of a hypertension biomarker was proposed using SPCE-Au. The label free method is based on ferric cyanide redox that has a low detection limit. The methods seems to becomparable with other immunosensor methods responsive to protein as biomarker, and could be assumed as a promising alternative technique 
for hypertension detection. This immunoassay method holds potential for detection of the biomarkers in clinical samples.

\section{Acknowledgement}

This research was supported by Ministry of Research, Technology, and Higher Education of Indonesia for Research Grant of Penelitian Dasar Unggulan Perguruan Tinggi Scheme, No.2776/UN6.D/LT/2019.

\section{References}

[1] E. Tabashi, A., Noorbakhsh, A., \& Sharifi, "Reduced graphene oxide chitosanaptamer interface as new platform for ultrasensitive detection of human epidermal growth factor receptor 2.," Biosens. Bioelectron., pp. 1-24, 2012.

[2] J. C. Miller, J.N., \& Miller, "Statistics and Chemometrics for Analytical Chemistry, Sixth Edition, Pearson Education Limited, England.," 2010.

[3] \& W. R. H. Ronkainen, N. J., H. B. Halsall., "Electrochemical Biosensors.," Chem. Soc. Rev., 2008.

[4] \& H. S. R. Parkash, O., Y. Y. Chan., "Screen Printed Carbon Electrode Based Electrochemical Immunosensor For the Detection of Dengue NS1 Antigen. Diagnostics.," vol. 4, pp. 165-180, 2015.

[5] M. \& D. G. Boeckl, "Self-Assembled Monolayers: Advantages of Pure Alkanethiols.," Mater. Matters., vol. 3, pp. 1-5, 2006.

[6] G. Ravalli, A., Pilon, G., Ferroni, M., Faglia, G., Yamanaka, H., \& Marrazza, "Sensors and Actuators B : Chemical New label free CA125 detection based on gold nanostructured screen-printed electrode.," Sensors Actuators B. Chem., vol. 179, pp. 194-200, 2013.

[7] \& N. J.-R. Braiek, M., K. B. Rokbani, A. Chrouda, B. Mrabet, A. Bakhrouf, A. Maaref., "An Electrochemical Immunosensor for Detection of Staphylococcus aureus Bacteria Based on Immobilization of Antibodies on Self-Assembled MonolayersFunctionalized Gold Electrode.," Biosensors., vol. 2, pp. 417-426, 2012.

[8] W. D. \& G. Z. Hu, C., "Enzime Immunosensor Based on Gold Nanoparticles Electroposition and Streptavidin-biotin System for Detection of S. pullorum \& S. gallinarum. Electrochimca Acta.," vol. 117, pp. 239-245, 2014.

[9] \& M. S. Arkan, E., R. Saber, Z. Karimi., "A Novel Antibody-Antigen Based Impedimetric Immunosensor for Low Level Detection of HER2 in Serum Samples of Breast Cancer Patients via Modification of a Gold Nanoparticles Decorated Multiwall Carbon Nanotube-Ionic Liquid Electrode.," Anal. Chim. Acta., 2015.

[10] G. Wahyuni, H.Y., Misonia, B.S.U., Santhy, W., \& Shabarni, "A Voltammetric Immunosensor for Detection of HER2 using Gold Modified-Screen Printed Carbon Electrode.," J. Chem. Environ., vol. 22(Ii), pp. 294-301, 2018.

[11] \& R. J. F. Baradoke, A., B. Jose., R. Pauliukaite, "Properties of Anti-CA125 antibody layers on screen-printed carbon electrodes modified by gold and platinum nanostructures.," Electrochim. Acta., vol. 306, pp. 299-306, 2019.

[12] \& H. J. . Guyton, A.C., "Buku Ajar Fisiologi Kedokteran. Alih Bahasa: Irawati, S., L.M.A. K. A. Tengadi \& A. Santoso.," Jakarta EGC., 1997.

[13] \& C. K. K. Yang, Y.J., J. Kim., "Association of Genetic Variation in the Epithelial Sodium Channel Gene with Urinary Sodium Excretion and Blood Pressure.," Nutr. 
Dep. Prev. Med. Coll. Med. Hanyang Univ. Korea., 2018.

[14]R. M. A. Sofiatin, Y \& Roesli, "Detection of Urinary Epithelial Sodium Channel (ENaC) Protein.," Am. J. Clin. Med. Res. Dep. Public Heal. Fac. Med. Univ. Padjadjaran Bandung., vol. 6, pp. 20-23, 2018.

[15]A. G. Su, Y. R \& Menon, "Epithelial Sodium Channels and Hypertention. Drug Metabolism and Disposition.," Dep. Mol. Genet. Biochem. Microbiol. Univ. Cincinnati Med. Center, Cincinnati, Ohio., vol. 29 No.4, 2001.

[16]A. Hanukoglu, I \& Hanukoglu, "Epithelial Sodium Channel (ENaC) Family: Phylogeny, Structure-function, Tissue Distribution, and Associated Inherited Diseases.," Gene, pp. 95-132, 2016. 